\title{
Changes in Lake Rotcze catchment over the last 200 years: implications for lake development reconstruction
}

\author{
Grzegorz Andrzej Kowalewski \\ Department of Biogeography and Palaeoecology, A. Mickiewicz University, Poznań, Dzięgielowa 27, 61-680 Poznań; \\ e-mail: ichtys@amu.edu.pl
}

\begin{abstract}
Based on archival cartographic sources, teledetection materials, and research results in the scope of history and environmental sciences, changes occurring in the catchment of Lake Rotcze and its close vicinity over the last two hundred years were analysed. The area of the catchment is dominated by moderately fertile minerogenic soils on which forest assemblages developed (poor hornbeamoak forest Tilio-Carpinetum and thermophilous oak forest Potentillo albae-Quercetum). The first trace of anthropopressure was a clearing at the southern shore of the lake, for agricultural use, established not later than at the turn of the $17^{\text {th }}$ and $18^{\text {th }}$ century. The forests were almost completely cleared in the first quarter of the $20^{\text {th }}$ century, and transformed into cultivated land of the village of Grabniak. A large fragment of the catchment is occupied by peatlands, constituting the final stage of lake-peatland succession developed in the former bay of fossil Lake Uściwierskie of which Lake Rotcze constitutes the remains. During the $20^{\text {th }}$ century, the peatlands were intensively drained. This resulted in their overdrying, and growing over with bushes and marshy forests. In the $20^{\text {th }}$ century, Grabniak was an agricultural village. Over the last 25 years, it has turned into a recreation resort. The relatively short agricultural and settlement activity in the lake catchment, in comparison with other parts of Poland, makes the lake appropriate for palaeolimnological reconstruction in terms of looking for reference conditions (sensu WFD).
\end{abstract}

Key words: Łęczna-Włodawa Lake District, Uściwierskie Lowering, Rotcze Lake, catchment changes, Heldensfeld’s map

\section{Introduction}

Reconstructions of limnic system transformations are usually performed by means of palaeogeographic and palaeoecological research. These studies cover long periods of time, because transformations of lakes already began at the end of the last glacial (Błaszkiewicz 2007; Wilgat 1954). Therefore, changes revealed by palaeo methods usually refer to events occurring over a period of several hundred to several thousand years. Registering changes occurring over decades and centuries requires multiproxy analyses and/ or higher resolution of sampling of study cores. Such studies are increasingly frequently conducted, focusing on the one hand on a period of rapid climate changes, like Late Glacial-Holocene (e.g. Birks and Wright 2000; Milecka et al. 2011; Kulesza et al. 2011) and on the other hand on a historical period (e.g. Gałka et al. 2013; Kowalewski et al. 2013; Lamentowicz et al. 2009). The latter develop particularly intensively, considering growing interest in the relations between humans and nature in the context of the ongoing climate changes.

The key element of the reconstruction of the development of a lake, apart from research on in-lake succession, is research on the transformations of its catchment, fundamentally affecting the limnic ecosystem (Bajkiewicz-Grabowska 2002). In the course of such transformations, the lake basin is filled with allochthonous sediments (Tobolski 2000), both developing in the lake itself (authigenic factors), and supplied from the catchment (allogenic factors). As a consequence, the lake bottom is first inhabited by submerged macrophytes, and then by rush vegetation and peat-forming assemblages. The development of the latter results in the development of a new, internal lake catchment, blocking matter inflow from the primary (mineral) catchment, and supplying the lake in matter from peatlands. In extreme situations, when peatland develops around the lake, peatland lakes are formed (Banaś et al. 2012). 
Transformations of catchments occur particularly intensively in the case of changes in land use. Over the last several hundred years, their intensity has continuously increased (e.g. Rasmussen and Anderson 2005). Therefore, detailed determination of such transformations by various methods is of key importance for accurate reconstructions. Most palaeoecological methods analyse changes occurring within the lake itself. The highest amount of information on the catchment is provided by pollen analysis. Its results, however, refer to various spatial scales, depending on plant pollination. This makes it difficult to separate changes referring to the lake catchment itself, particularly if the catchment occupies a small area. Therefore, historical sources, including archival cartographic and remote sensing materials, as well as studies on the history of settlement explaining changes in the land use in the catchment, are a valuable supplementation of palaeolimnological methods, if not an equivalent research tool, in studies on changes in the natural environment in the modern period, and particularly over the last 200 years (e.g. Goslar et al. 1999). For this period, numerous research materials are already available, which allow tracking the response of the limnic system to changes in the catchment recorded with high precision. The objective of this paper is to analyse the transformations of the catchment of Lake Rotcze, particularly those occurring over the last 200 years, on archival cartographic sources, teledetection materials, and research results in the scope of history and environmental sciences. The study results will support the ongoing reconstruction of transformations of Lake Rotcze itself.

\section{Materials and methods}

- Topographic maps at a scale of 1: 10,000 (geodetic coordinates 1965) prepared in 1976. This map was used as a background to interpret older, non metric maps.

- Monochromatic aerial photography from 1952.

- The Tactical Map of Poland of the Military Geodesic Institute at a scale of 1:100,000, the map sheet of Łęczna issued in 1936.

- Karte des westlichen Rußlands, at a scale of $1: 100,000$, based on maps at different scales $(1: 21,000,1: 42,000,1: 84,000$ and 1:126,000) issued at the turn of the $19^{\text {th }}$ and $20^{\text {th }}$ century.

- Topographical Map of the Kingdom of Poland of 1839 , at a scale 1:126,000 (Quartermaster Map).
- Carte of West-Gallizien by Anton Mayer von Heldensfeld, prepared in the years 1801-1804. The map was published in 1804 in the form of 275 coloured sheets at a scale of 1:28,800. This paper applies sheet 233 supervised in the field by lieutenant (Oberlieutenant) Wilhelm Tielke (Sawicki 1928). Unfortunately, the maps were created not based on reliable geodesic methods, but based on a rough triangulation network. Therefore, conducting measurements on the maps is not possible. However, the hydrographic content was presented in great detail. "Wie fein getont erscheinen die Ströme, wie lebendig die Altwässer, verwilderten Stromarme, [...] die gesonderte Darstellung der periodisch tätigen Flusse, erscheint hier schon durchgeführt. Quelltümpel, Sumpfe, Alluvialwiesen, Teiche mit sorgfältiger Dammzeichnung umgeben, weisen vielfach Signaturen auf, die lebhaft an die heute gebrauchten erinnern" (Sawicki 1928, p. 75). In later years, several maps scaled down based on the sheets at a scale of 1:28,800 were published, including a 12-sheet map at a scale of 1:172,800, prepared by Hieronymus Benedicti in 1808, and also used in this paper. The map involves numerous intentional deformations in relation to the original, but mainly concerning the land relief. Sawicki does not mention any inaccuracies in the representation of the drainage network.

- Satellite images from Google and Geoportal resources.

- Historical sources (Panasiuk 2013a).

\section{Results and discussion}

The catchment of Lake Rotcze is defined differently by various authors. The catchment area determined by Harasimiuk et al. (1998) and later followed by Smal et al. (2005) amounts to 157.19 ha. The analysis of changes in the area of the catchment by Suchożebrska and Chabudziński (2007) revealed a decrease in the area of the catchment from 241 ha (original catchment) to 101 ha in 2006. Dawidek et al. (2012) and Ferencz and Dawidek (2012) adopted the area of the surficial catchment amounting to $120 \mathrm{ha}$, and distinguished the underground catchment of 749 ha for which they also determined the share of particular types of sediments. Due to the adoption of various areas of the catchment for calculations, the share of organic soils in the works cited (Smal et al. 2005; Dawidek et al. 2012) differs considerably (49\% and 19\%, re- 
spectively), which affects the assessment of the degree of impact of the catchment on the lake. Dawidek et al. (2012) highlighted the importance of the Cretaceous hills in the southern part of the lake catchment in supplying the lake water and thus the lake sediments. The cutting off of this part of the catchment due to the development of natural (Kowalewski 2012) or artificial streams (Dawidek et al. 2012) should be taken into account, as this may significantly change the hydrogeochemical patterns of ground water feeding the lake.

\section{Pre-disturbance period}

The basin of Lake Rotcze is located at the eastern boundary of a channel constituting an arm of the Uściwierskie Lowering, formerly filled with waters of the single fossil Lake Uściwierskie. To the north and south, the basin of the fossil bay Rotcze (Fig. 1) was confined by mineral elevations of former peninsulas of fossil Lake Uściwierskie. On the other side of the northern peninsula, Lake Uściwierz is currently located, and on the other side of the southern peninsula, Lake Sumin. The lake level of the fossil lake Uściwierskie was controlled by threshold adjustment closing the Uściwierskie Lowering north from Lake Bikcze. This was anthropogenically changed at least before the turn of the $18^{\text {th }}$ and $19^{\text {th }}$ century as a result of cutting drainage ditches (Kowalewski 2012).

The channel in which modern Lake Rotcze is located is already largely filled with gyttja and peat (Okruszko et al. 1971), and the lake has only remained in its deepest part. To the south-east and east, the shore is high and sandy (Fijałkowski 1959), devoid of organic sediments as a result of wave action (Okruszko et al. 1971; comp. Dobrowolski et al. 2009). Other possible explanation of this phenomena will be address in subsequent publication.

At the northern and north-western shore, a narrow (several tens to more than $100 \mathrm{~m}$ ) belt of peat occurs with a thickness of 1-3 m (Popiołek 1988). The western and south-western shore is made of organic formations (peats on gyttja), and is largely inaccessible. Peatlands are overgrown with thin alder rushes and a large number of willows (Fijałkowski 1959). Reeds in the shore zone grow on a floating mat (Popiołek 1988). This fragment of the shore zone is genetically the youngest and the most dynamic.

The lake probably lost contact with the remaining waters of fossil Lake Uściwierskie on the isthmus on which the watershed of the modern lake is currently located (Fig. 1), although the course of the watershed

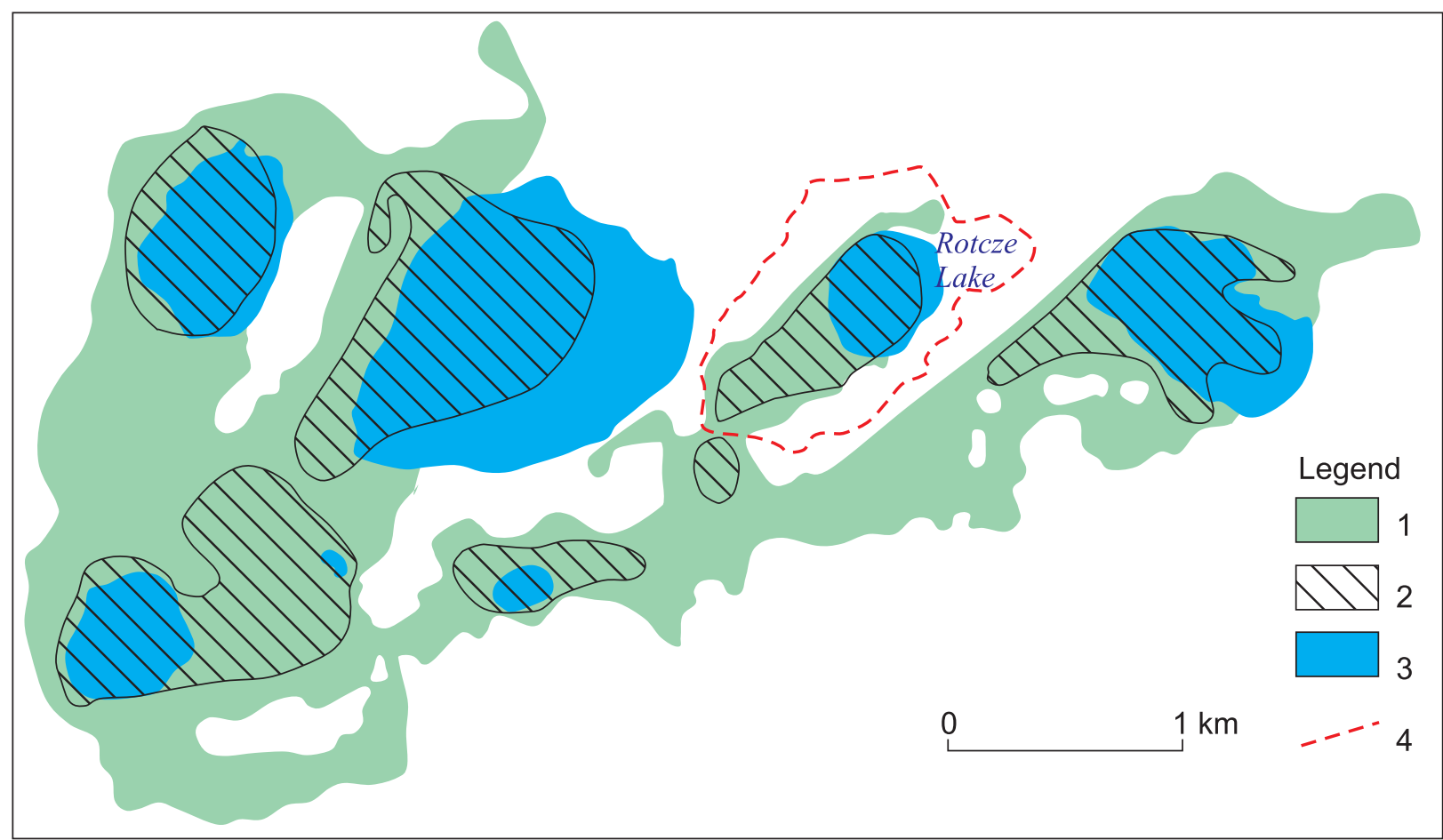

Fig. 1. Range of biogenic sediments in Uściwierskie Lowering acc. to Okruszko et al. (1971). Explanation: 1 - peatlands, 2 - gyttja, 3 modern lakes, 4 - border of the catchment 
does not consider the existing melioration ditches (compare Suchożebrska and Chabudziński 2007). No presence of gyttja was determined in the isthmus, although the thickness of peat exceeds $3 \mathrm{~m}$ (Okruszko et al. 1971). The basin of Lake Rotcze is the second deepest depression (following the basin of Lake Uściwierz) in the Uściwierskie Lowering. Its depth acc. to the geological cross-section exceeds $14 \mathrm{~m}$, counting from the water surface (Okruszko et al. 1971, Fig. 3). Another geological cross-section, perpendicular to the former one, determines the depth of the basin at $10 \mathrm{~m}$ (op. cit. Fig. 4), and the drilling at $11 \mathrm{~m}$ below the current water level. As in other lakes of the Uściwierskie Lowering, considerable variability of the content of the components of gyttja, and particularly $\mathrm{CaCO}_{3}$, suggests high dynamics of groundwaters supplying the lake. The source of calcium carbonate is calcareous Cretaceous rocks underlying mineral Pleistocene formations (Dawidek et al. 2012). At a depth of $650-700 \mathrm{~cm}$, Okruszko et al. (1971) even determined the presence of detritus gyttja with a content of $\mathrm{CaO}$ of only $3.3 \%$. This may result from changing hydrogeochemical patterns of ground water supplying the lake and/or lake level fluctuation.

The disappearance of the open water surface probably proceeded from the isthmus mentioned above towards the modern lake. This is suggested by the elongated shape of the shoreline of the lake presented on the oldest maps (Fig. 2). The presence of assemblages of marshy coniferous forest Vaccinio uliginosi-Pinetum (Popiołek 1988), accompanied by small fragments of plant communities Caricetum limosae and Caricetum rostratae suggests that the overgrowing of the lake proceeded by floating mat encroachment. Marshy coniferous forest as potential vegetation is also determined by Matuszkiewicz (2008) in the northern and north-western shore zone.

According to Matuszkiewicz (2008), thermophilous oak forest Potentillo albae-Quercetum assemblages were adjacent to the eastern shore, with their range confined to the lake's catchment. The south-eastern shore, on the peninsula, was overgrown by poor dry ground forests Tilio-Carpinetum. They

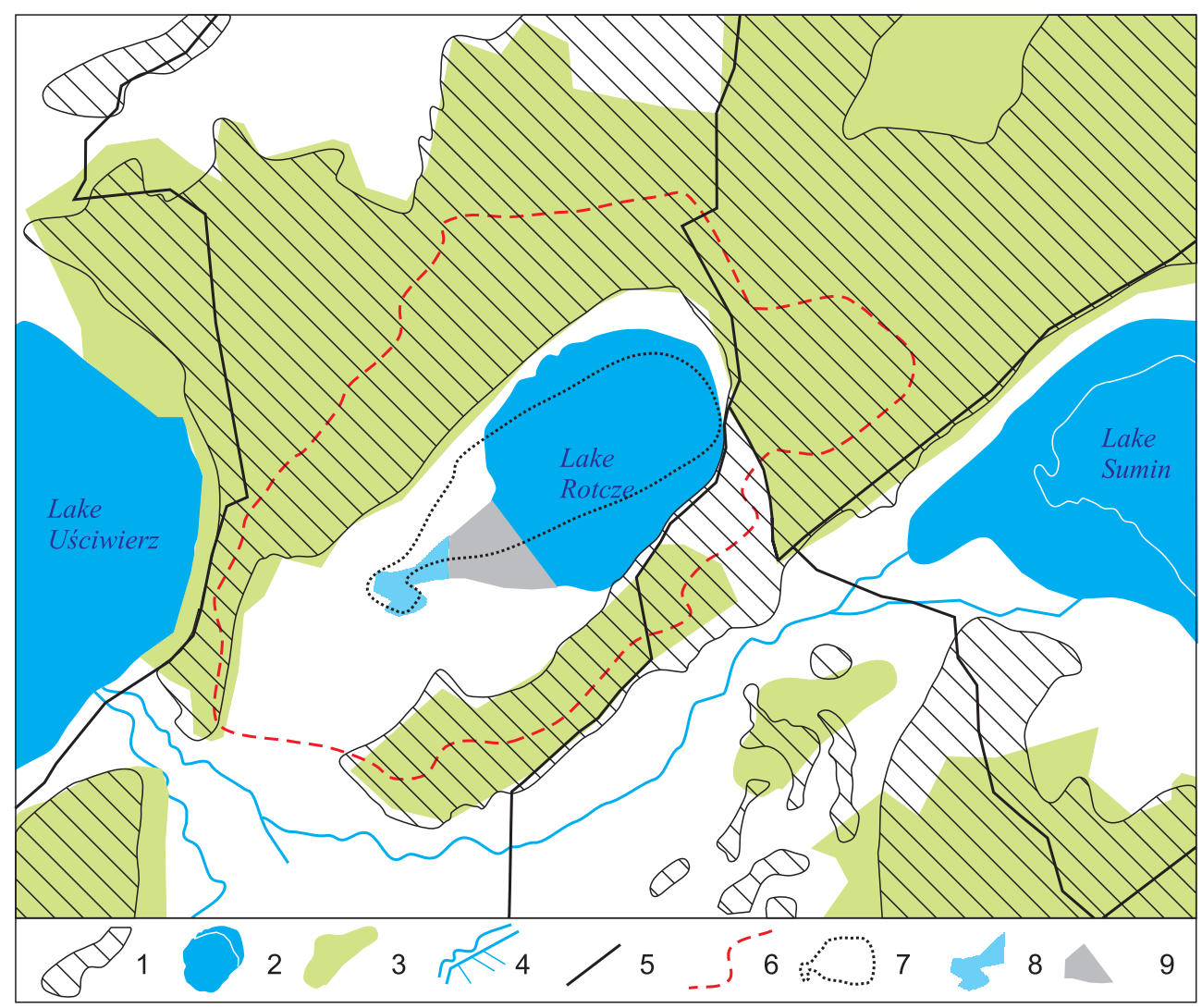

Fig. 2. Interpretation of the Heldensfeld map (1804) on the background of a topographical map 1:10,000. Explanation: 1 - mineral ground, 2 - lake, 3 - forest, 4 - stream, canal, drainage ditch, 5 - road, 6 - border of the catchment. Contours redrawn and reinterpreted from the Heldensfeld map: 7 - line of lake shore, 8 - wet area, 9 - forest between the lake and wet area 
also surrounded the lake's catchment to the north and east. The primary catchment was therefore overgrown by forest assemblages inhabiting moderately fertile soils. The name of the village of Grabniak, surrounding the modern lake on three sides, was derived from the Polish common name of one of the forest-forming components, namely hornbeam (Carpinus betulus; Polish - grab). This is a classic toponym, as also stated by Panasiuk (2013a): "Grabniak probably owes its name to the hornbeam forest occurring in the area."

\section{First traces of anthropopressure}

According to the oldest map by Heldensfeld from 1804 (Fig. 2), the lake was surrounded by wetlands, and to the east and south-east, by a dense forest. The wetland belt to the north was narrow. Behind it, a dense forest area also extended. To the south, the forest was cleared for the purpose of land cultivation and/or animal breeding. The peninsula was connected with the village of Garbatówka, located south of the Uściwierskie Lowering, with two roads, already vis- ible on the map by Heldensfeld. One of them is also marked on the Quartermaster Map (Fig. 3). The road connected Garbatówka with Zawadówka, and further Wola Wereszczyńska. In autumn and spring, it was probably inaccessible in the early $19^{\text {th }}$ century, as was the road Wola Wereszczyńska-Wereszczyn (Panasiuk 2013b). A similar pattern of agricultural land was marked on the Quartermaster Map.

On the map by Heldensfeld, the lake's shape is somewhat elongated along the longer axis of the fossil bay. Additionally, to the south of the lake, small open water surfaces are marked. This suggests late overgrowing of the water surface, as confirmed by studies by Żurek (manuscript), who documented a thickness of the encroaching floating mat of only $0.5 \mathrm{~m}$ based on geological corings in the Uściwierskie Lowering.

\section{Development of settlement}

According to Panasiuk (2013a), the beginning of settlement around the lake dates back to the turn of the $19^{\text {th }}$ and $20^{\text {th }}$ century. The first record from 1905

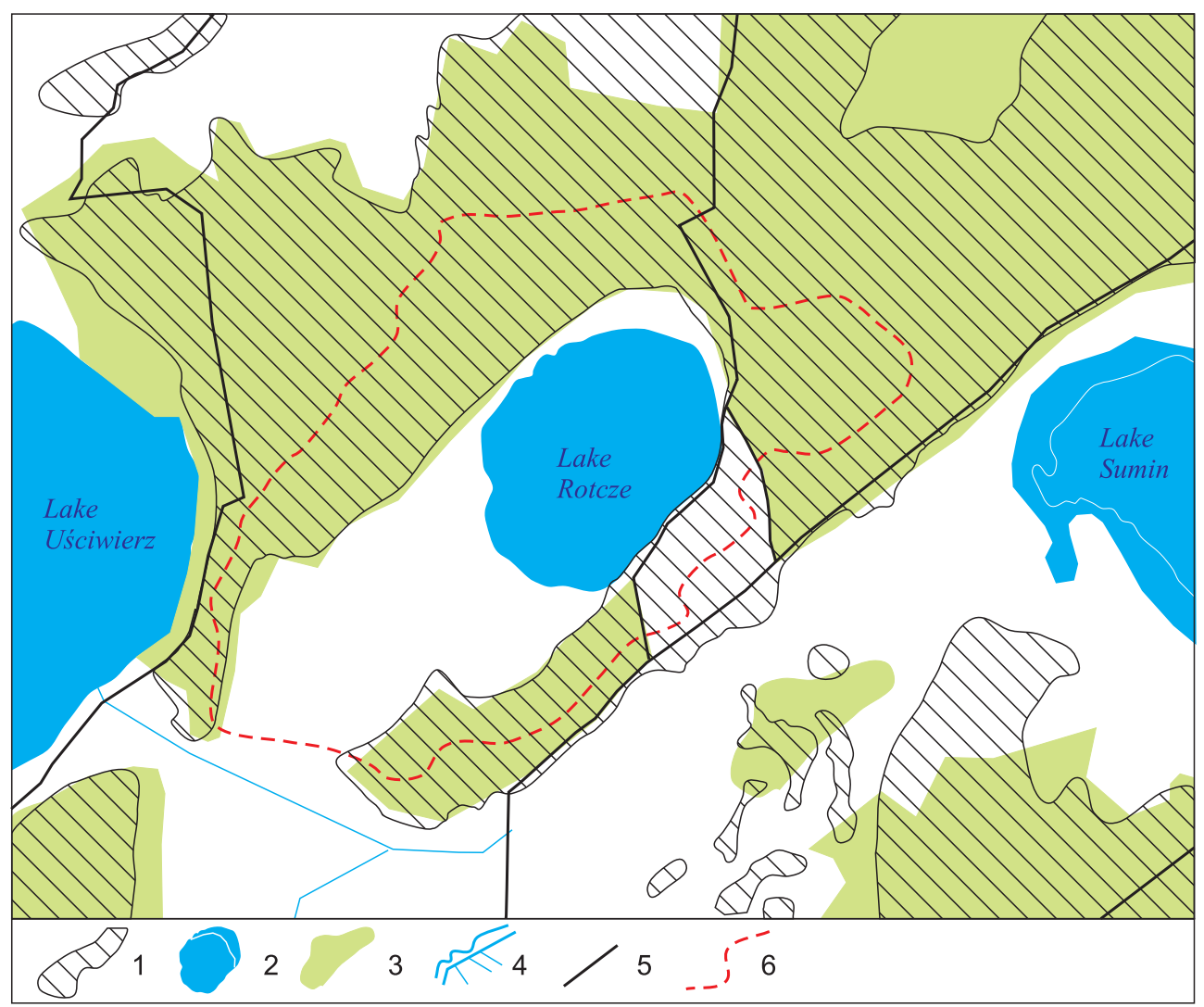

Fig. 3. Interpretation of the Quartermaster map (1839) on the background of a topographical map 1:10,000. Explanation: 1 - mineral ground, 2 - lake, 3 - forest, 4 - stream, canal, drainage ditch, 5 - road, 6 - border of the catchment 
includes information on 276 inhabitants residing in 38 houses. Two maps come from the period: one from 1911 (Fig. 4), and Karte des Westlichen Russland from 1915. The younger of the maps (1915) was prepared based on the map from the turn of the $19^{\text {th }}$ and $20^{\text {th }}$ century, and includes content from the period preceding the establishment of the settlement. It was already outdated when it was issued. It does not even include the clearing on the peninsula. The fragments with no forest north of the lake were marked as wetlands.

Spezialkarte der Osterreichisch-Ungarischen Monarchie from 1911 (year of update) reflects the reality in a much more accurate manner. First of all, a large area of the catchment was deforested, including the eastern shore of the lake. On the map, forest is adjacent to the lake only on the peninsula. The area between Lakes Uściwierz and Rotcze was deforested. Unfortunately, the topographic content of the map does not accurately reflect the reality. The representation of the development of the village of Grabniak, and the course of the road east of the lake are very inaccurate. A total of 15 households were marked on the map, which is not the entire development recorded in the population count. In Fig. 4, households were marked in places of their potential location, considering younger, more accurate maps, but always the closest to the location on the map from 1911, retaining their number. The oldest geodetic maps come from 1896 (kolonia Baraki) and 1909. The latter presents the division of land into parcels east and north of the lake. It can be presumed that each parcel had a separate household. According to this information, the map from 1911 would be missing at least three. Similarly, the map of kolonia Baraki documents five households, whereas the map from 1911 only three. During the First World War, the population of Grabniak continuously changed. Some of the inhabitants were relocated to Russia, and the surrounding area constituted the war front. To sum up, settlement in the direct vicinity of the lake (on the eastern shore) has existed at least from the beginning of the $20^{\text {th }}$ century. Sewage and waste from the households could constitute the source of pollutants and biogenes for the lake.

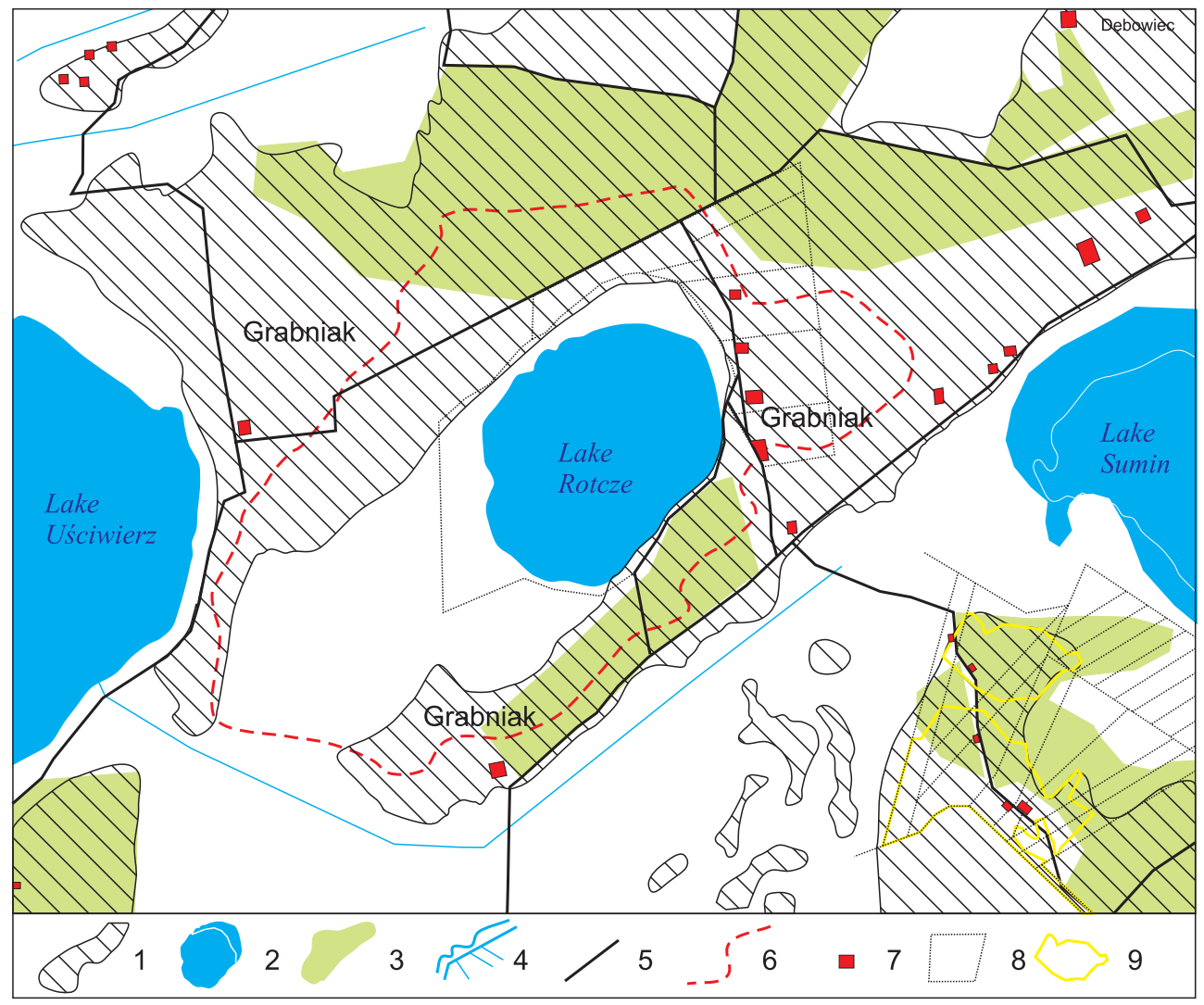

Fig. 4. Interpretation of the Karte des westlichen Rußlands (1911) on the background of a topographical map 1:10,000. Explanation: 1 mineral ground, 2 - lake, 3 - forest, 4 - stream, canal, drainage ditch, 5 - road, 6 - border of the catchment, 7 - building, 8 - border of lots acc. to geodetic plans of Baraki (1896) and Rotcze (1909), 9 - mineral ground on the Baraki plan (1909) 
In the interwar period, the number of houses increased from 53 in 1921 to 70 before the outbreak of the Second World War (Panasiuk 2013a; the map from 1936 shows 63 households). The village was inhabited by more than 300 people. The analysis of the map WIG 1:100,000 revealed substantial changes both in the terrestrial and wetland area of the catchment. As a result of an increase in the population and development of agriculture, forests in the analysed area were cleared almost completely, and wetlands southwest of the lake were meliorated by means of numerous ditches (Kowalewski 2012). A significant contribution to the supply of biogenes to the lake was made by the melioration ditch inflowing to the lake from the north, but draining the eastern part of the catchment. It already functioned at the beginning of the 1950's, as documented by aerial photographs, but it is not marked on the map from 1936.

In the entire history of the study area, the most considerable changes in the catchment occurred in the first quarter of the $20^{\text {th }}$ century. In further years, they were only followed by an increase in the density of development, which, however, multiplied the effect on the lake itself. During the 40 years from 1936 to 1976, the land management was not subject to any significant changes (Fig. 5-6). Forests slowly developed on wetlands, particularly in the SE direction from the lake as a result of their drying, and agriculture was the dominant form of anthropogenic activity. On the other hand in the peatland north of the lake only single trees grew along the drainage ditches and rushes were hardly present along the shore line until the early 1950's. Peat cutting resulted in many peat holes located inside the treeless peatland surface. The digging of a melioration canal Bogdanka-Wola Wereszczyńska in the 1960's, however, resulted in substantial hydrographic disturbance in the catchment. In particular, the ditch completely separated the northern part of the lake catchment (compare Suchożebrska and Chabudziński 2007). It caused the most significant water level lowering in the lake, which definitely lost its natural hydrological status during the period, earlier disturbed with digging melioration ditches in the interwar period (Kowalewski 2012).

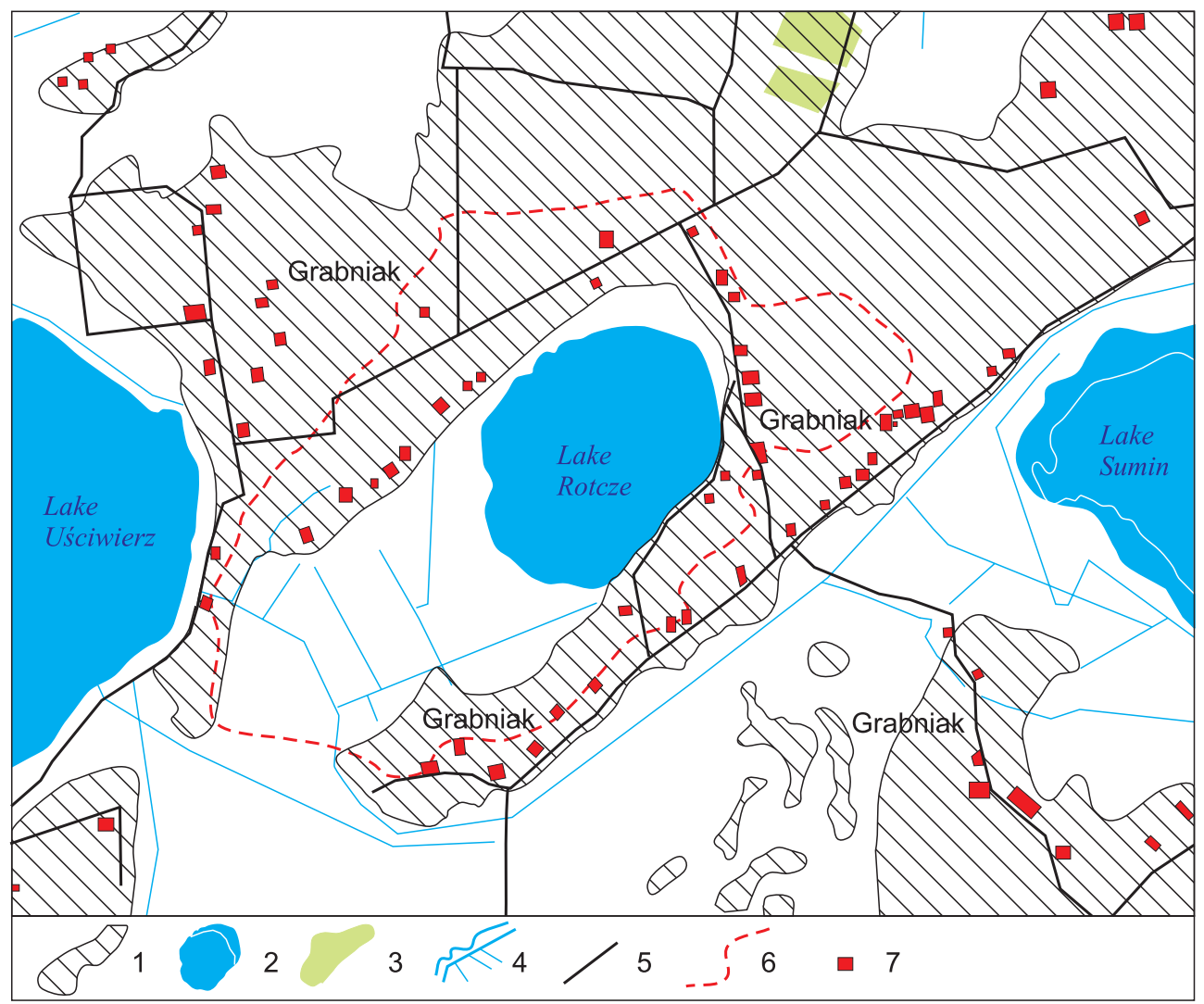

Fig. 5. Interpretation of the Tactical Map of Poland (1936) on the background of a topographical map 1:10,000. Explanation: 1 - mineral ground, 2 - lake, 3 - forest, 4 - stream, canal, drainage ditch, 5 - road, 6 - border of the catchment, 7 - building 


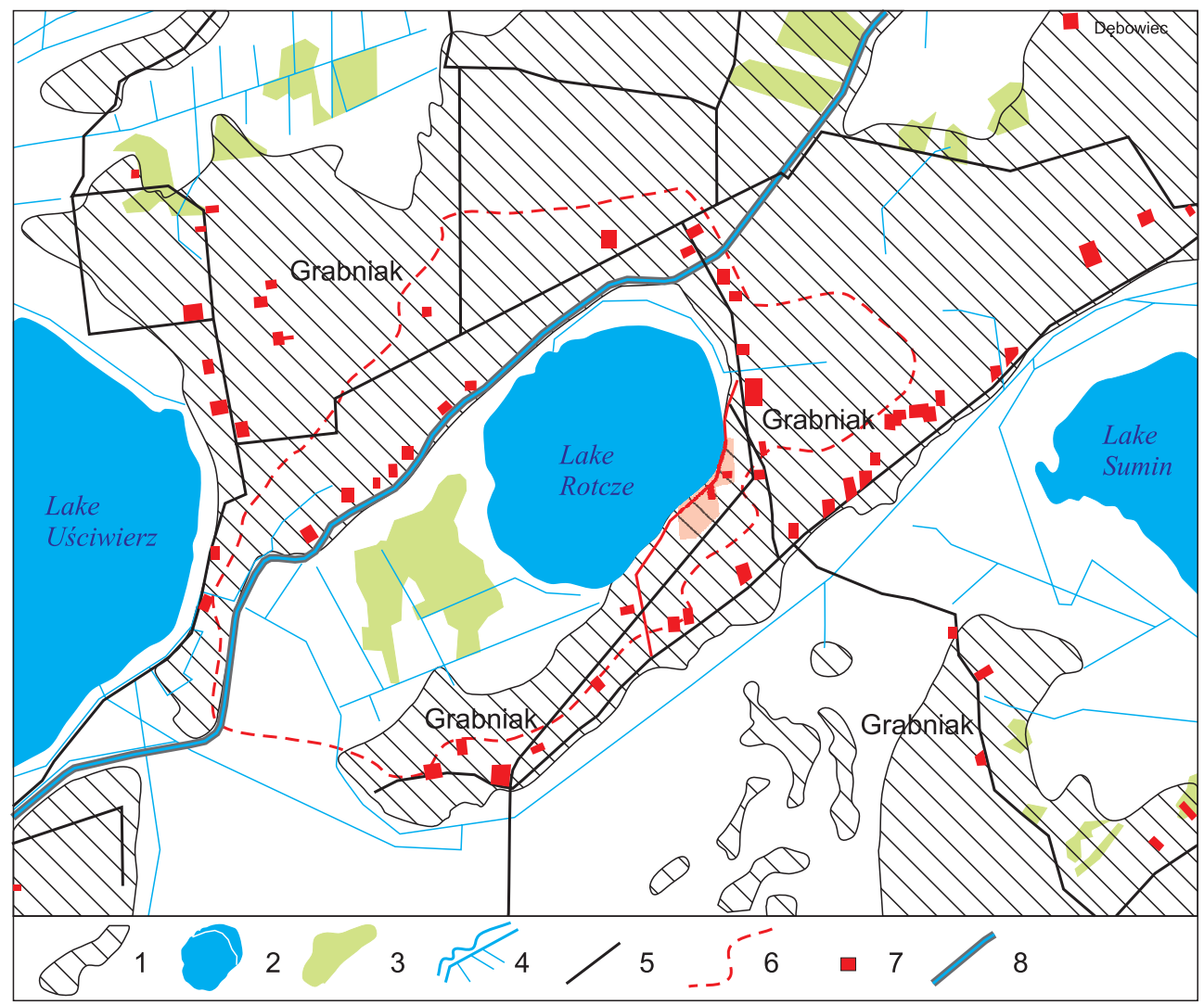

Fig. 6. Topographical Map of Poland (1976). Explanation: 1 - mineral ground, 2 - lake, 3 - forest, 4 - stream, canal, drainage ditch, 5 road, 6 - border of the catchment, 7 - building, 8 - melioration canal Bogdanka - Wola Wereszczyńska

Since the 1970's, the lake has become a popular place of recreation, and at the beginning of the 1980's, the village began transforming into a holiday resort. The recreational exploration of the lake began with ZHP (Polish scouting association) building a training and recreation centre (Panasiuk 2013a).

The development of summer houses was very random, and the lake became the recipient of sewage. Similar transformations occurred in the part of Grabniak located in the vicinity of Lake Uściwierz. The maximum tourist pressure was recorded in 1998 (Chmielewski and Jankowska 2009). Although the number of permanent inhabitants in the early $21^{\text {st }}$ century oscillated around 150, i.e. was twice as low as before the Second World War, the population is multiplied in the summer season (Fig. 7). A satellite image from 2010 (Fig. 8) revealed an important increase in the area of rushes and floating-leaf communities in comparison with the early 1950's, with many clearings in the rush belt due to recreational activity.

\section{Conclusion}

The area of the catchment of Lake Rotcze and its direct vicinity was subject to substantial changes over the last 200 years, but retained its nearly pristine hydrological state almost until the end of the $19^{\text {th }}$ century, with only slight transformations in land cover in the catchment. Forests were cleared in the first quarter of the $20^{\text {th }}$ century, and transformed into agricultural land. The peatland part of the catchment was transformed in the 1920's (meliorations) and 1950's (irrigation canal at the boundary of the peatland). This resulted in a water level decrease in the lake. Several tens of agricultural farms were replaced by hundreds of recreational houses until the end of the $20^{\text {th }}$ century. The relatively young age of transformations in the catchment permits the tracing of its changes not only based on palaeoecological studies, but also based on numerous historical sources, and particularly maps. This substantially supports palaeolimnological recon- 


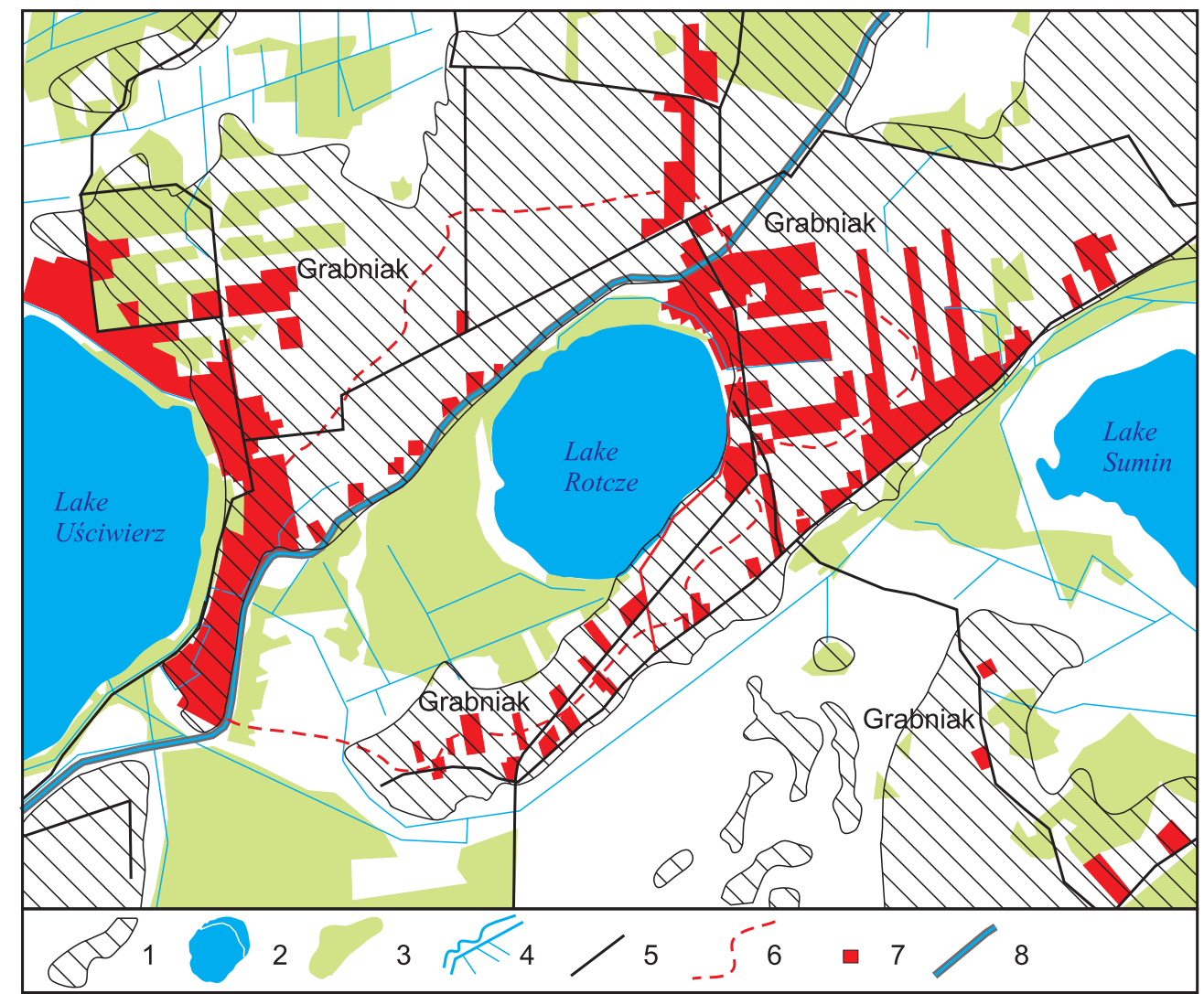

Fig. 7. Topographical Map of Poland updated acc. to satellite images from 2010. Explanation: 1 - mineral ground, 2 - lake, 3 - forest, 4 stream, canal, drainage ditch, 5 - road, 6 - border of the catchment, 7 - building, 8 - melioration canal Bogdanka - Wola Wereszczyńska

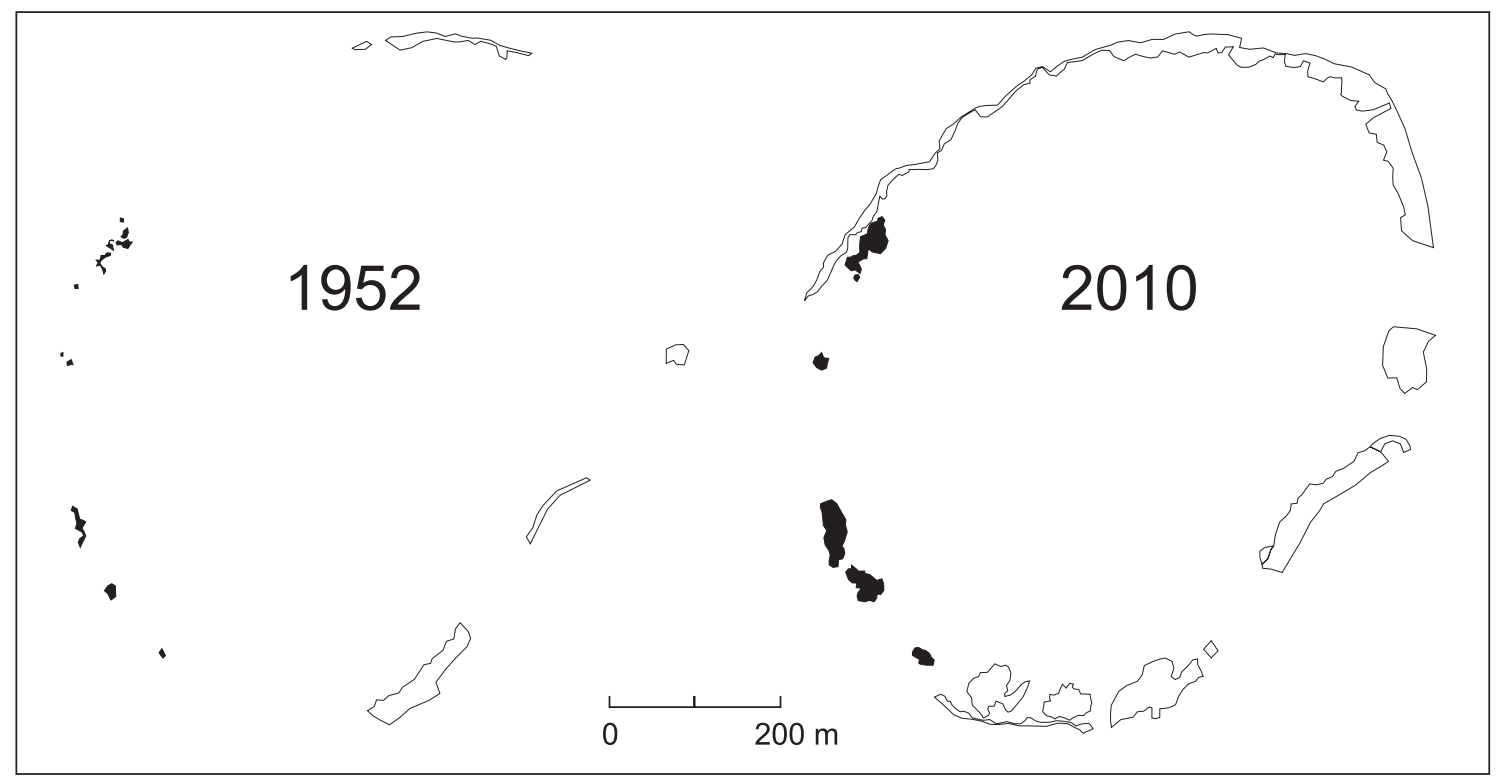

Fig. 8. Comparison of the range of emerged (black outline) and floating-leaved (black) vegetation between the aerial photograph from 1952 and the satellite image from 2010 
structions, permitting a more accurate explanation of the causes of particular stages of the lake's development. Therefore, Lake Rotcze is valuable as an object under low anthropopressure, allowing studies on anthropogenic changes but starting from pre-disturbance conditions. Such objects, although common, for example, in Australia (Tibby 2003), are rare in Europe.

\section{References}

Bajkiewicz-Grabowska E., 2002, Obieg materii w systemach rzeczno-jeziornych (Circulation of matter in the riverlake systems), Wyd. UW, Warszawa, p. 274 (in Polish, English summary).

Banaś K., Gos K., Szmeja J., 2012, Factors controlling vegetation structure in peatland lakes - Two conceptual models of plant zonation, Aquat. Bot. 96: 42-47.

Birks H.H., Wright Jr. H.E., 2000, Introduction to the reconstruction of the late-glacial and early-Holocene aquatic ecosystems at Kråkenes Lake, Norway, J. Paleolim. 23: $1-5$.

Błaszkiewicz M., 2007, Geneza i ewolucja mis jeziornych na młodoglacjalnym obszarze Polski - wybrane problemy (Origin and evolution of lake basins on early postglacial landscape - selected issue), Stud. Lim. et Tel. 1: 5-16 (in Polish).

Chmielewski T.J., Janakowska P., 2009, Changes in the level and structure of tourism on selected lakes of Łęczna-Włodawa Lakeland from 1985 to 2008, [In:] Chmielewski T.J., Sławiński C. (eds), Nature and landscape monitoring system in West Polesie region, University of Lifie Science, Institute of Agrophysics Polish Academy of Sciences, Lublin: 243-256.

Dawidek J., Ferencz B., Sobolewski W., 2012, Modelling of hydrogeochemical potential of three lake catchments in Polesie region (Eastern Poland), Hydrol. Process. 27(12): 1773-1780.

Dobrowolski R., Bałaga K., Rodzik J., Gazda L., 2009, Bottom deposits of Lake Moszne in the Polesie National Park - lithostratigraphy and palaeoenvironmental interpretation, Teka Kom. Ochr. Kszt. Środ. Przyr. - OL PAN 6: 51-57.

Ferencz B., Dawidek J., 2012, Water exchange of three shallow Łęczna-Włodawa lakes, Limnol. Rev. 12: 65-72.

Gałka M., Tobolski K., Górska A., Milecka K., FiałkiewiczKozieł B., Lamentowicz M., 2013, Disentangling the drivers of a Baltic bog development during the Little Ice Age in northern Poland, Quatern. Int. (Available online 28 February 2013) doi.org/10.1016/j.quaint.2013.02.026).

Goslar T., Ralska-Jasiewiczowa M., Geel B., Łącka B., Szeroczyńska K., Chróst L., Walanus A., 1999, Anthropogenic changes in the sediment composition of Lake Gościąż (central Poland), during last 330 yrs, J. Paleolim. 22: 171-185.
Fijałkowski D., 1959, Szata roślinna jezior ŁęczyńskoWłodawskich i przylegających do nich torfowisk (Flora of the Łęczyna-Włodawa lakes and the peat bogs adjoining them), Ann. UMCS B 14(3): 131-206 (in Polish, English summary).

Harasimiuk M., Michalczyk Z., Turczyński M., 1998, Jeziora Łęczyńsko-włodawskie. Monografia przyrodnicza (Łęczna-Włodawa Lakes. A monographic study), Biblioteka Monitoringu Środowiska, Wyd. UMCS, Lublin, p. 176 (in Polish).

Kowalewski G., 2012, Over 200 years of drainage practices and lake level drawdown in Uściwierskie Lowering (Łęczna-Włodawa Lake District), Limnol. Rev. 12(4): 179-190.

Kowalewski G.A., Kornijów R., McGowan S., Woszczyk M., Suchora M., Bałaga K., Kaczorowska A., Gąsiorowski M., Szeroczyńska K., Wasiłowska A., 2013, Persistence of protected, vulnerable macrophyte species in a small, shallow eutrophic lake (eastern Poland) over the past two centuries: Implications for lake management and conservation, Aquat. Bot. 106: 1-13.

Kulesza P., Suchora M., Pidek I.A., Alexandrowicz W.P., 2011, Chronology and directions of Late Glacial paleoenvironmental changes: A multi-proxy study on sediments of Lake Słone (SE Poland), Quatern. Int. 238(12): 89-106.

Lamentowicz M., Milecka K., Gałka M., Cedro A., Pawlyta J., Piotrowska N., Lamentowicz L., van der Knaap W.O., 2009, Climate and human-induced hydrological change since AD 800 in an ombrotrophic mire in Pomerania (N Poland) tracked by testate amoebae, macro-fossils, pollen, and tree-rings of pine, Boreas 38: 214-229.

Matuszkiewicz J. M., 2008, Potencjalna roślinność naturalna Polski (Potential natural vegetation of Poland), IGiPZ PAN, Warszawa.

Milecka K., Kowalewski G., Szeroczyńska K., 2011, Climaterelated changes during the Late Glacial and early Holocene in northern Poland, as derived from the sediments of Lake Sierzywk, Hydrobiologia 676(1): 187-202.

Okruszko H., Churski T., Karpińska J., 1971, Torfowiska i gytiowiska $\mathrm{w}$ rejonie jezior krasowych Uściwierz na Pojezierzu Łęczyńsko-Włodawskim (Mires and gyttja areas in the region of Uściwierz karst lakes in ŁęcznaWłodawa Lake District), Zesz. Probl. Post. Nauk Rol. 107: 121-165 (in Polish).

Panasiuk A., 2013a, Dzieje wsi Grabniak (History of Grabniak village). Retrieved from http://historia.urszulina. net (in Polish).

Panasiuk A., 2013b, Śladami zapomnianej historii... Wola Wereszczyńska (Tracking the forgotten history... Wola Wereszczyńska). Retrieved from http://historia.urszulina.net (in Polish). 
Popiołek Z., 1988, Zróżnicowanie roślinności wodnej i przybrzeżnej na tle warunków siedliskowych w obrębie kompleksu jezior Lubelskiego Zagłębia Węglowego (Differentiation of submerged and telmatic plants versus habitat condition in the lakes of Lublin Coalmining area), Rozpr. Wydz. Biologii i nauk o Ziemi 35 Wyd UMCS, Lublin, p. 108 (in Polish).

Rasmussen P., Anderson N.J., 2005, Natural and anthropogenic forcing of aquatic macrophyte development in a shallow Danish lake during the last 7000 years, J. Biogeogr. 32: 1993-2005.

Sawicki L., 1928, Pułkownika Antoniego barona Mayera von Heldensfelda zdjęcia topograficzne w Polsce w latach 1801-1804 (Colonel Anthony baron Mayer von Heldensfeld's topographic works in Poland in the years 1801-1804), Pr. Inst. Geogr. UJ 10: 5-111 (in Polish, German summary).
Smal H., Kornijów R., Ligęza S., 2005, The effect of catchment on water quality and eutrophication risk of five shallow lakes (Polesie Region, eastern Poland), Pol. J. Ecol. 53(3): 313-327.

Suchożebrska M., Chabudziński Ł., 2007, Anthropogenic Transformations of the Hydrographical Network in Lake Catchment Areas of the Uściwierz Lowering (Łęczna-Włodawa Lake District), Limnol. Rev. 7: 225-231.

Tibby J., 2003, Explaining lake and catchment change using sediment derived and written histories: an Australian perspective, Sci. Total Environ. 310: 61-71.

Tobolski K., 2000, Przewodnik do oznaczania torfów i osadów jeziornych. (Guidebook to Peat and Lake Sediment Determination), PWN, Warszawa, p. 501 (in Polish).

Wilgat T., 1954, Jeziora Łęczyńsko-Włodawskie (The Łęczna-Włodawa lakes), Ann. UMCS B 8(3): 37-121 (in Polish, English summary). 